\title{
Pheromones in marine algae: a technical approach
}

\author{
G. Gassmann ${ }^{1}$, D. G. Müller ${ }^{2}$ \& P. Fritz \\ 1 Biologische Anstalt Helgoland, Zentrale Hamburg; Notkestraße 31, D-22607 Hamburg, \\ Germany \\ 2 Universität Konstanz, Fakultät für Biologie; Postfach 5560, D-78434 Konstanz, \\ Germany \\ ${ }^{3}$ Normag, Labor- und Verfahrenstechnik GmbH; Feldstraße 1, Postfach 1269, D-65719 \\ Hofheim am Taunus, Germany
}

\begin{abstract}
It is now well known that many marine organisms use low-molecular volatile substances as signals, in order to coordinate activities between different individuals. The study of such pheromones requires the isolation and enrichment of the secretions from undisturbed living cells or organisms over extended periods of time. The Grob-Hersch extraction device, which we describe here, avoids adverse factors for the biological materials such as strong water currents, rising gas bubbles or chemical solvents. Furthermore, the formation of sea-water spray is greatly reduced. The application of this technique for the isolation of pheromones of marine algae and animals is described.
\end{abstract}

\section{INTRODUCTION}

The first three sexual pheromones of marine algae (ectocarpene: Müller, 1967; Müller et al., 1971; fucoserratene: Müller \& Jaenicke, 1973, Jaenicke \& Seferiadis, 1975; multifidene: Müller, 1974; Jaenicke et al., 1974) were isolated from seawater containing female gametes by applying a simple $\mathrm{CO}_{2}$-cooled trap. This kind of purge-and-trap procedure is prone to a lot of drawbacks: large amounts of biological materials are needed, which is very time-consuming; the enrichment factor is very low; the risk of losing the collected, volatile substances is high; the separation of the excretion product from the water phase is incomplete, and the cross-contamination from outside is destructive. Between 1973-1975 the Grob family, and Grob \& Zürcher (1976), introduced an elegant purge-and-trap procedure designed as a closed-loop system. This extraction technique avoids all the drawbacks of a cold trap. Nevertheless, one single disadvantage common to all purge-and-trap procedures remained: the spray formed by rising and bursting gas bubbles in solute-rich aqueous media, like seawater. Each rising and bursting gas bubble creates several film and jet droplets, which quickly form sea-salt crystals when drying (Blanchard \& Syzdek, 1975; Wu, 1980). An incomplete separation of the phases and a fast clogging of the charcoal filter trap are the consequences of this phenomenon.

In 1962, P. Hersch (cf. Gilroy \& Mayne, 1962) developed an ingenious de-aeration scrubber which not only de-oxygenates aqueous solutions beneath the detection limit of 
oxygen, but also completely avoids the jet-droplet formation by bursting bubbles. Although it constituted significant progress, this work remained largely unnoticed by the scientific community. The combination of both Grob's and Hersch's principles leads to an extraction device which is especially suitable for investigations in seawater.

\section{MATERIALS AND METHODS}

The procedure for the accumulation of female gametes from field material or cultured algae are described in various reports by Müller et al. between 1971-1988. The technique for bio-assays of natural and synthetic pheromones have been described by Müller (1976).

A $2-\mathrm{dm}^{3}$ Hersch vessel equipped with a cooling jacket and an all-glass heatable filter holder (cf. Boland et al., 1984) was manufactured by Normag (Hofheim, Germany). The adsorptive filter trap, loaded with $1.5 \mathrm{mg}$ of activated charcoal and packed as a narrow slice between stainless steel sieves, was purchased from Brechbühler (Schlieren, Switzerland). An inert (stainless steel and graphite) magnetically-clutched gas-circulating micropump (G 24/02; $160 \mathrm{~g}$ weight) was obtained from H. Brey (Memmingen, Germany).

A general description of the closed-loop stripping process and a detailed report of the extraction procedure of the charcoal filter trap with organic solvents were given by Grob (1973), Grob \& Grob (1974), Grob et al. (1975), Grob \& Zürcher (1976), and Cooney et al. (1983). In our work, the charcoal filters were eluted with $30-\mu l$ di-chloro-methane.

Gas-chromatographic separations and detections of algal extracts were carried out on Carlo Erba gas chromatographs (Type GC 2900) equipped with dual on-column injectors and flame-ionisation detectors (FID). Each extract was separated on fused silica capillary columns coated with stationary phases of different polarities (Carbowax 20M or OV101). Hydrogen $(30-50 \mathrm{kPa})$ was used as carrier gas. We used the following temperature programme: $25^{\circ} \mathrm{C}$ for $5 \mathrm{~min}$ isothermal, $5^{\circ} \mathrm{C} / \mathrm{min}$, final temperature $220^{\circ} \mathrm{C}$. Signals were recorded by electronic integrators (Spectra-Physics [SP-4100 and SP-4200]).

Purified compounds from algal extracts were obtained by the following technique: after each analytical gas-chromatographic run of an algal extract, the electrode-head of the FID was removed, and the flame on the FID-tip extinguished. The end of the analytical column was prepared for connection to an N-shaped micro-trap made of a 100 mm-long glass capillary tube filled with silica-gel particles. The trap was cooled with solid $\mathrm{CO}_{2}$ and connected to the column whenever a peak of interest passed a selected retention time window. 10 to 20 separate peaks could be selectively trapped by this method. Each trap loaded with a single peak was instantly sealed at its ends with a microburner (propane/oxygen), and stored in a fridge until some of the silica-gel (Spherosil) particles were removed and used as artificial pheromone sources in a bio-assay.

If necessary, the same peak in multiple runs was accumulated in one empty $\mathrm{N}$ shaped cold trap. Such preparations were then investigated further, by mass-spectrometrometry and chemical reactions. Due to the very low amounts of material in the range of nano- to micrograms, the structure elucidation of an unknown bio-active substance could only be achieved by trial-and-error syntheses. The identity of a synthetic molecule with its natural analogue was established by its bio-activity, identical retention times on capillary columns of different polarities, and identical mass spectrograms. 


\section{RESULTS}

The closed-loop stripping (CLS) device according to Grob is shown in Figure $1 \mathrm{~A}$. The construction principle is simple. A bottle, partially filled with the aqueous sample, is equipped with stripping utilities consisting of a gas pump $(\mathrm{P})$, an adsorptive filter $(\mathrm{F})$, and a gas dispersion tube inserted deep down into the aqueous phase and ending with a
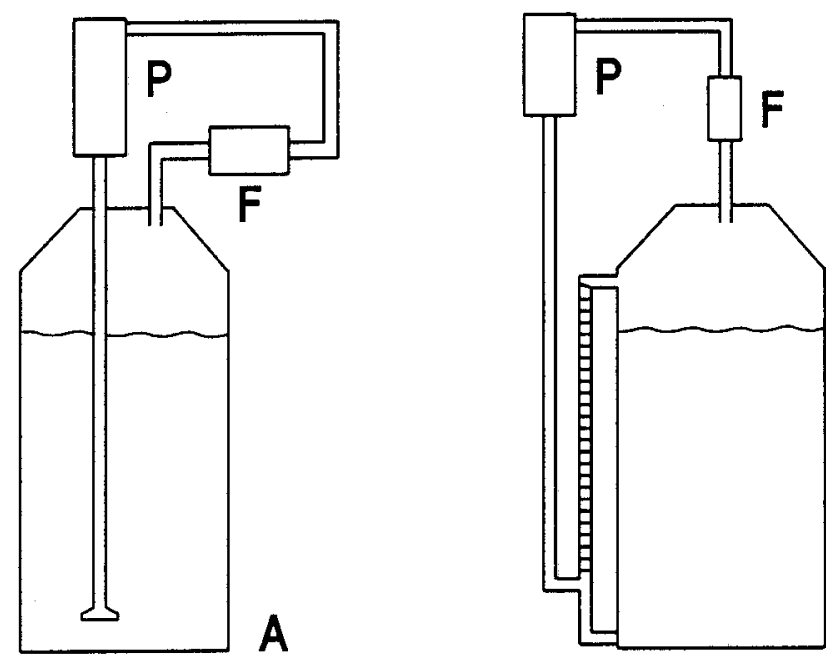

B

Fig. 1. Operational scheme of a closed-loop purge-and-trap device according to Grob (A) and to Grob-Hersch (B)

fritted glass disk. The working principle is well-known: air over the liquid phase is sucked up by the pump, passing first the filter, then the inert pump-head, and finally returning to the liquid phase. Rising air bubbles sweep volatile constituents out of the water phase onto the solid phase of the adsorptive filter material. This Grob CLS device is best-suited for all kinds of trace analyses with short stripping times. It presents drawbacks, when longer stripping times are necessary and when samples rich in solutes are investigated. In such cases, the formation of jet droplets from bursting bubbles causes clogging of the filter trap. This can be prevented by combining the Grob CLS principle with a stripping vessel design, as shown in Figure 1 B. Here, bubble formation takes place inside a glass tube outside the main vessel. The internal diameter of the glass tube (5-6 $\mathrm{mm}$ ) leads to the formation of single gas bubbles, which are interspersed by a short section of water. The final bubble-bursting event at the upper orifice of the tube differs substantially from the normal bubble-bursting process. Since the bubble-carrying tube ends above the level of the liquid phase of the main vessel, the transported water returns in a smooth flow. The gas section forms a bubble film at and around the tube orifice, which eventually bursts and forms only a reduced number of film droplets. If the tube is elongated and coiled around the main vessel, the Hersch principle is added to the structure (Fig. 2). The resulting Grob-Hersch extraction device shows additional advantages beside the jet droplet prevention. Firstly, filter clogging is reduced and extraction 

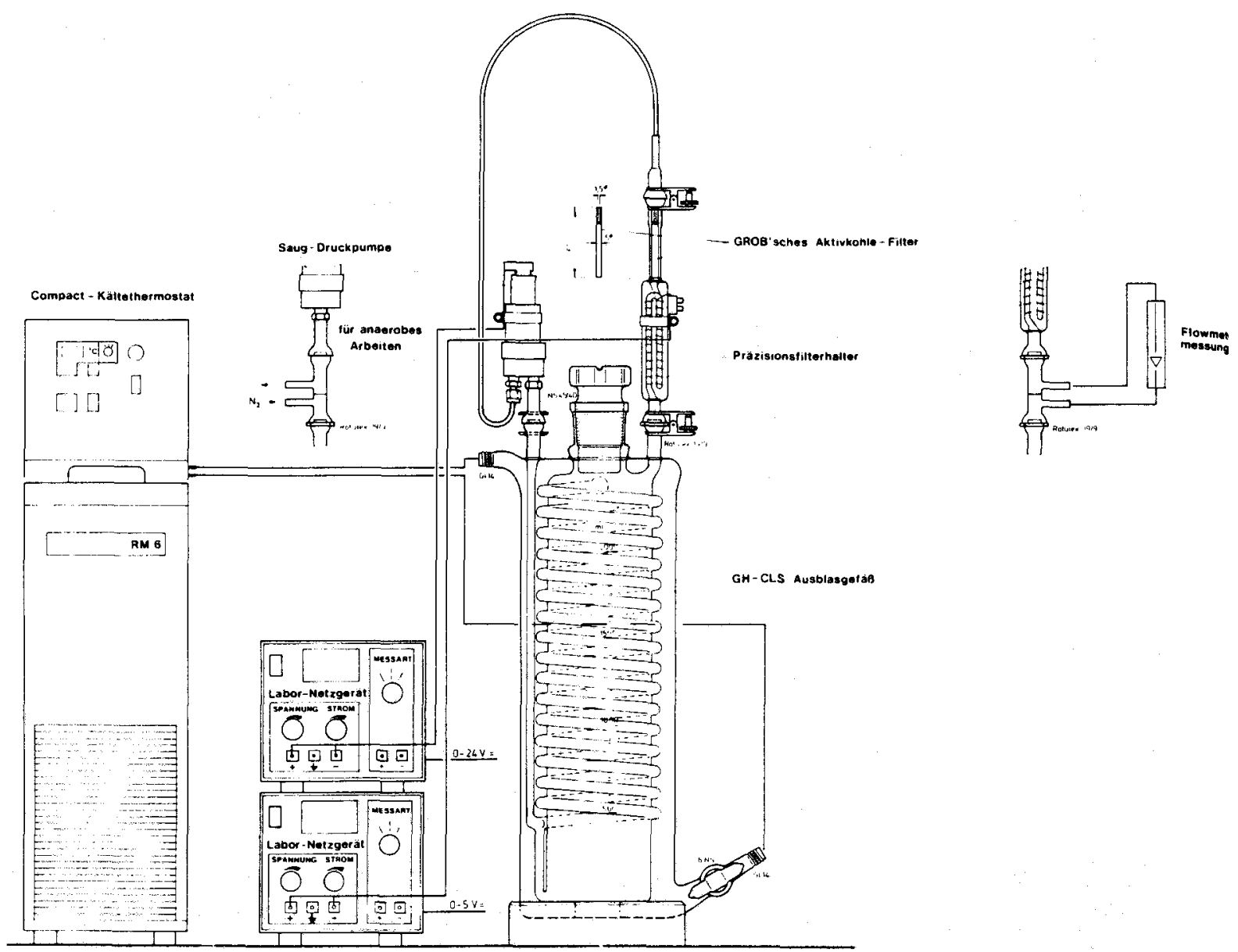

Fig. 2. Diagram of a Grob-Hersch extraction device with a 2-dm ${ }^{3}$ Hersch vessel (GH-CLS Ausblasgefäß) with cooling jacket, a heatable all-glass filter holder (Präzisionsfilterhalter), a gascirculating pump (Saug-Druckpumpe), a filter with a $1.5 \mathrm{mg}$ active charcoal packing (Grob'scheAktivkohle-Filter), power supplies (Labor-Netzgerät), and a cryostate (Compact-Kältethermostat)

times can be extended to the range of weeks, even with sea-water samples. Secondly, the diffusion of volatiles from the gas phase back into the liquid phase is reduced. Thirdly, the rising gas and water bubbles inside the tube have the effect of an internal elevator, lifting water from below to above. This already-stripped water builds up a layer over the lesser-stripped water, supporting the stripping efficiency even more. These secondary effects add up to the almost complete shift of volatiles from the liquid into the gas phase.

The following simple experiment illustrates the stripping efficiency of the combined Grob-Hersch technique: the water surface inside the main vessel is adjusted higher than the upper orifice of the bubble-carrying tube. Consequently, the gas bubbles have to break through the water surface similar to the simple Grob extraction pattern. Under 
these conditions the stripping efficiency falls back to the normal level. This effect can be easily quantified by measuring the de-oxygenation of water stripped with ultra-pure nitrogen in an open Hersch vessel. While the proper Hersch process (open upper orifice) diminishes the oxygen level below the detection limit of $0.1 \mu \mathrm{g} \mathrm{kg}{ }^{-1} \mathrm{O}_{2}$ within a few hours, the simple Grob-type stripping condition (upper orifice immersed in the liquid phase) reaches its limit at an $\mathrm{O}_{2}$ level of about $100 \mathrm{\mu g} \mathrm{kg}^{-1}$, even after prolonged stripping times (Gassmann, 1973).

In marine biology, the Grob-Hersch extraction device is ideally suited for the detection of volatile natural products like algal pheromones. Female gametophytes, mature oogonia or fertile eggs can be incubated inside a Hersch vessel under optimal conditions. Salinity, temperature, nutrients and illumination can be administered and

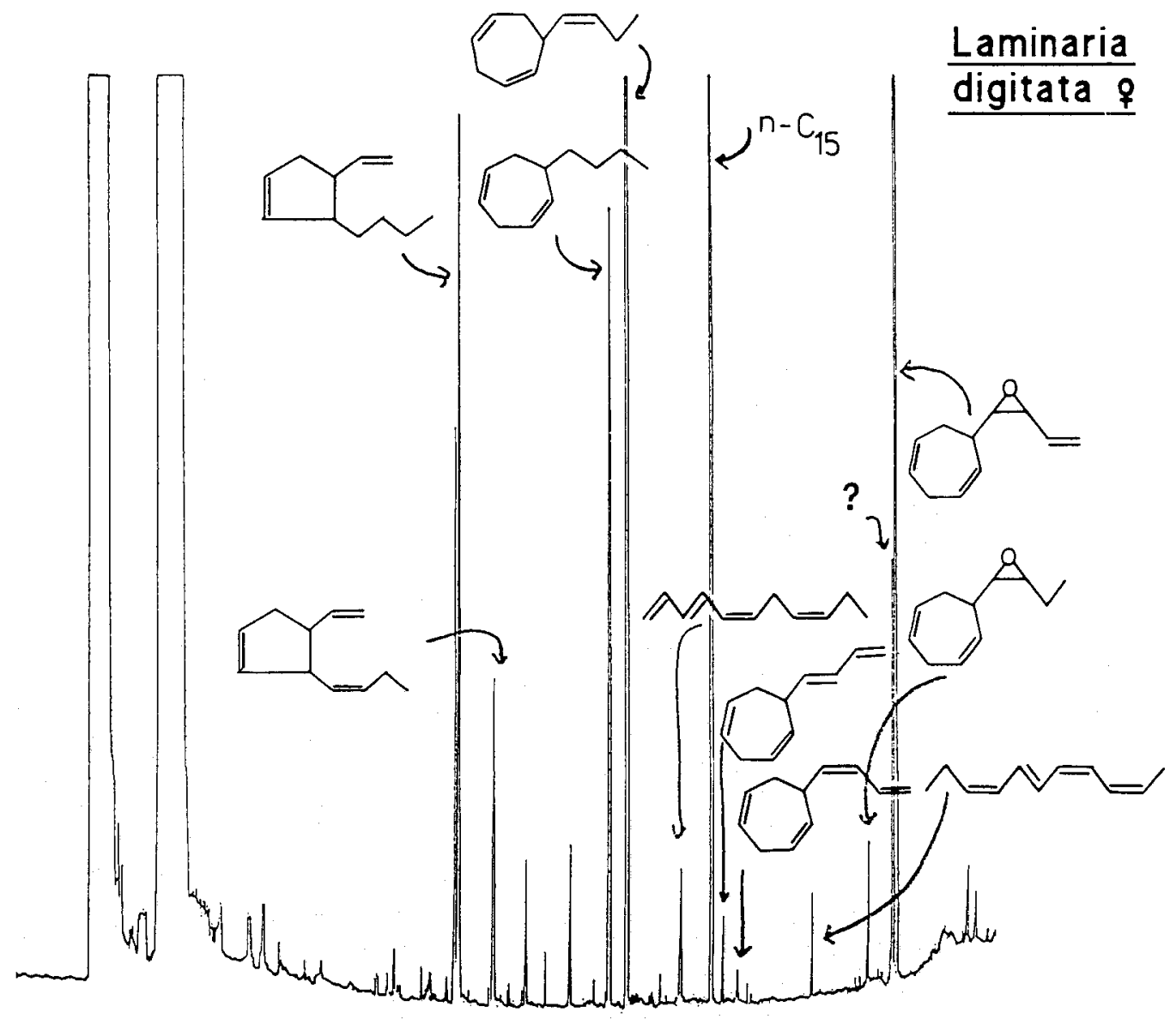

Fig. 3. Gas chromatogram of volatile excretions from the eggs of Laminaria digitata (Phaeophyceae, Laminariales). $0.2 \mu \mathrm{l}$ (of $30-\mu \mathrm{l}$ di-chloro-methane filter extract) were on-column injected onto a Supelcowax 10 , fused silica capillary column $(60 \mathrm{~m} \times 0.32 \mathrm{~mm} \times 0.25 \mu \mathrm{m})$. Hydrogen as carrier gas $(50 \mathrm{kPa})$. Temperature programme: $25^{\circ} \mathrm{C}(5 \mathrm{~min})-5^{\circ} \mathrm{C} / \mathrm{min}-220^{\circ} \mathrm{C}$. Detector: FID. Carlo-Erba gas chromatograph GC 2900 
controlled, while continuous or intermittent extraction of volatile excretion products takes place.

Figure 3 shows a gas chromatogram of volatile excretion products from mature Laminaria digitata eggs including the sexual pheromone lamoxirene. Most of the prominent peaks are hydrocarbons with a $C_{11}$ carbon skeleton and their epoxides. $N$-pentadecane $\left(n-C_{15}\right)$ is part of the unspecific background, which is produced by many marine algae.

1.<smiles>CC/C=C\C1C=CCC=CC1</smiles>

2.

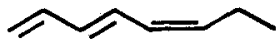

3.<smiles>C=CC1CC=CC1/C=C\CC</smiles>

4.<smiles>CCCCCC1C=CCC=CC1</smiles>

5.<smiles>C=C/C=C\C1C=CCC=CC1</smiles>

6.<smiles>C=C/C=C\C1C=CCC1C=C</smiles>

7.

8.

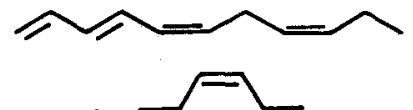

9.<smiles>C=CC1CC1C=CC1OC1C1C=CCC=CC1</smiles>

10.

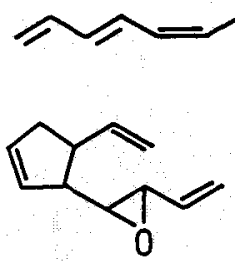

Ectocarpene 1971

\section{Fucoserratene} 1973

Multifidene 1974

Dictyopterene C 1981

Desmarestene 1982

Viridiene 1982

Finavarrene

1982

\section{Hormosirene} 1984

\section{Lamoxirene}

1985

\section{Cystophorene 1985}

\section{Caudoxirene 1988}

Fig. 4. Known sexual pheromones of marine brown algae (Phaeophyceae) 
The Grob-Hersch CLS device was used to establish the occurrence of fucoserratene as the sperm attractant in several species of the genus Fucus (Müller \& Gassmann, 1978). Subsequently, several new sexual pheromones (Fig. 4) could be detected and their structure elucidated (Müller et al., 1979, 1981a, 1981b, 1982, 1984, 1985; Marner et al., 1984 ; Boland et al., 1985, 1987). By application of the same techniques, the sexual pheromone of the marine polychaete Platynereis dumerillii could be enriched and identified as a ketone with a $\mathrm{C}_{8}$ carbon-skeleton (5-methyl-3-heptanone) (Zeeck et al., 1988).

\section{CONCLUSION}

The successful application of the Grob-Hersch CLS to the study of algal pheromones illustrates that this technique is excellently suited to study volatile compounds in saline media. Its application can be expanded to the extraction of moderately polar substances by the addition of salt (such as $\mathrm{Na}_{2} \mathrm{SO}_{4}$ ) to a solute-poor solution (Friant \& Suffet, 1979). Such treatments can shift the vapour-phase partitioning into the desired direction. This technique can extend the range of the extraction pattern, which normally ends at the boiling point of octadecane $\left(\mathrm{C}_{18} \mathrm{H}_{38}\right.$; b.p. $\left.316.1^{\circ} \mathrm{C}\right)$, to include the boiling-point range from docosane $\left(\mathrm{C}_{22} \mathrm{H}_{46} ;\right.$ b.p. $\left.368.6{ }^{\circ} \mathrm{C}\right)$ to tricosane $\left(\mathrm{C}_{23} \mathrm{H}_{48} ;\right.$ b.p. $380.2{ }^{\circ} \mathrm{C}_{i}$ Gassmann, 1993, unpubl.).

Lately, we have been using the Hersch vessel for studies of the phosphine biosynthesis in the hydro- and biosphere. In this context, the Hersch vessel produces oxygenfree sodium-hydroxide solution, which is essential for the detection of phosphine in $\mathrm{PH}_{3}$ bearing matrices (Gassmann \& Schorn, 1993; Gassmann \& Glindemann, 1993).

Acknowledgement. The financial support provided for the second author, Dieter G. Müller, by the Deutsche Forschungsgemeinschaft (DFG), is gratefully acknowledged.

\section{LITERATURE CITED}

Blanchard, D. C. \& Syzdek, L. D., 1975. Electrostatic collection of jet and film drops. - Limnol. Oceanogr, 20, 762-774.

Boland, W., Ney, P., Jaenicke, L. \& Gassmann, G., 1984. A "closed-loop-stripping" technique as a versatile tool for metabolic studies of volatiles. In: Analysis of volatiles. Ed. by P. Scheuer. De Gruyter, Berlin, 371-380.

Boland, W., Jaenicke, L. \& Müller, D. G., 1985. Viridiene - the male gamete attractant of the brown alga Syringoderma phinneyi - has 3R, $4 S$-configuration. - Naturwissenschaften 72, 147-148.

Boland, W., Jaenicke, L., Müller, D. G. \& Gassmann, G., 1987. Giffordene, 2Z, 4Z, 6E, 8Zundecatetraene, is the odoriferous principle of the marine brown alga Giffordia mitchellae. Experientia 43,466-467.

Cooney, D. O., Nagerl, A. \& Hines, A. L., 1983. Solvent regeneration of activated carbon. - Wat. Res. $17,403-410$.

Friant, S. L. \& Suffet, I. H., 1979. Interactive effects of temperature, salt concentration, and $\mathrm{pH}$ on head space analysis for isolating volatile trace organics in aqueous environmental samples. Analyt. Chem. 51, 2167-2172.

Gassmann, G., 1973. Untersuchung zur Isolierung und Struktur von Metallproteiden aus Clostridium pasteurianum. Diss., Univ. Tübingen, $136 \mathrm{pp}$.

Gassmann, G. \& Glindemann, D., 1993. Phosphan $\left(\mathrm{PH}_{3}\right)$ in der Biosphäre. - Angew. Chem. 105, 749-751. (Angew. Chem. int. Ed. 32, 761-763.) 
Gassmann, E. \& Schorn, F., 1993. Phosphine from harbor surface sediments. - Naturwissenschaften 80, 78-80.

Gilroy, D. \& Mayne, J. E. O., 1962. The de-aeration of aqueous solutions. - J. appl. Chem. 12, 382-384.

Grob, K., 1973. Organic substances in potable water and in its precursors. Pt I. Methods for their determination by gas-liquid chromatography. - J. Chromatogr. 84, 255-273.

Grob, K. \& Grob, G, 1974. Organic substances in potable water and in its precursors. Pt II. Application in the area of Zürich. - J. Chromatogr. 90, 303-313.

Grob, K. \& Zürcher, F., 1976. Stripping of trace organic substances from water: equipment and procedure. - J. Chromatogr. 117, 285-294.

Grob, K., Grob, K. jr. \& Grob, G., 1975. Organic substances in potable water and in its precursors. Pt III. The closed-loop stripping procedure compared with rapid liquid extraction. - J. Chromatogr. 106, 299-315.

Jaenicke, L. \& Seferiadis, K., 1975. Die Stereochemie von Fucoserraten, dem Gametenlockstoff der Braunalge Fucus serratus L. - Chem. Ber. 108, 225-232.

Jaenicke, L., Müller, D. G. \& Moore, R. E., 1974. Multifidene and Aucantene, $\mathrm{C}_{11}$ hydrocarbons in the male-attracting essential oil from the gynogametes of Cutleria multifida (Smith) Grev. (Phaeophyta). - J. Am. chem. Soc. 96, 3324-3325.

Marner, F. J., Müller, B. \& Jaenicke, L., 1984. Lamoxirene. Structural proof of the spermatozoid releasing and attracting pheromone of Laminariales. - Z. Naturf. 39C, 689-691.

Müller, D. G., 1967. Ein leicht flüchtiges Gyno-Gamon der Braunalge Ectocarpus siliculosus. Naturwissenschaften 54,496-497.

Müller, D. G., 1974. Sexual reproduction and isolation of the sex attractant in Cutleria multifida (Smith) Grev. (Phaeophyta). - Biochem. Physiol. Pflanz. 165, 212-215.

Müller, D. G., 1976. Quantitative evaluation of sexual chemotaxis in two marine brown algae. - Z . Pflanzenphysiol. 80, 120-130.

Müller, D. G. \& Gassmann, G., 1978. Identification of the sex attractant in the marine brown alga Fucus vesiculosus, - Naturwissenschaften $65,389$.

Müller, D. G. \& Jaenicke, L., 1973. Fucoserraten, the female sex attractant of Fucus serratus L. (Phaeophyceae). - FEBS Lett. 30, 137-139.

Müller D. G., Jaenicke, L., Donike, M. \& Akintobi, T., 1971. Sex attractant in a brown alga: chemical structure. - Science, N. Y. 171, 815-817.

Müller, D. G., Gassmann, G. \& Lüning, K., 1979. Isolation of a spermatozoid-releasing and -attracting substance from female gametophytes of Laminaria digitata. - Nature, Lond. 279, 430-431.

Müller, D. G., Gassmann, G., Boland, W., Marner, F. \& Jaenicke, L., 1981a. Dictyota dichotoma (Phaeophyceae): identification of the sperm attractant. - Science, N. Y. 212, 1040-1041.

Müller, D. G., Marner, F.-J., Boland, W., Jaenicke, L. \& Gassmann, G., 1981b. Identification of a volatile gamete secretion in Spermatochnus paradoxus. - Naturwissenschaften 67, 478-479.

Müller, D. G., Peters, A., Gassmann, G., Boland, W., Marner, F.-J. \& Jaenicke, L., 1982. Identification of a sexual hormone and related substances in the marine brown alga Desmarestia. - Naturwissenschaften 69, 290-292.

Müller, D. G., Clayton, M. N., Gassmann, G., Boland, W., Marner, F.-J. \& Jaenicke, L., 1984. The sperm attractant of Hormosira banksii (Phaeophyceae, Fucales), a seaweed common to Australia and New Zealand. - Experientia 40, 211-212.

Müller, D. G., Clayton, M. N., Gassmann, G., Boland, W., Marner, F.-J., Schotten, T. \& Jaenicke, L., 1985. Cystophorene and hormosirene, sperm attractants in Australian brown algae. - Naturwissenschaften 72, 97-99.

Müller, D. G., Boland, W., Becker, U. \& Wahl, T., 1988. Caudoxirene, the spermatozoid-releasing and attracting factor in the marine brown alga Perithalia caudata (Phaeophyceae, Sporochnales). - Biol. Chem. Hoppe-Seyler 369, 655-659.

Wu, J., 1981. Evidence of sea spray produced by bursting bubbles. - Science, N. Y. 212, 324-326.

Zeeck, E., Hardege, J., Bartels-Hardege, H. \& Wesselmann, G., 1988. Sex pheromone in a marine polychaete: determination of the chemical structure. - J. exp. Zool. 246, 285-292. 